\title{
The profile and contribution of rare germline copy number variants to cancer risk in Li-Fraumeni patients negative for TP53 mutations
}

\author{
Amanda G Silva ${ }^{1 *}$, Ana CV Krepischi ${ }^{1,2}$, Peter L Pearson ${ }^{1}$, Pierre Hainaut ${ }^{3}$, Carla Rosenberg ${ }^{1}$
} and Maria Isabel Achatz ${ }^{4}$

\begin{abstract}
Background: The Li-Fraumeni syndrome (LFS) is an inherited rare cancer predisposition syndrome characterized by a variety of early-onset tumors. Although germline mutations in the tumor suppressor gene TP53 account for over $50 \%$ of the families matching LFS criteria, the lack of TP53 mutation in a significant proportion of LFS families, suggests that other types of inherited alterations must contribute to their cancer susceptibility. Recently, increases in copy number variation (CNV) have been reported in LFS individuals, and are also postulated to contribute to LFS phenotypic variability.
\end{abstract}

Methods: Seventy probands from families fulfilling clinical criteria for either Li-Fraumeni or Li-Fraumeni-like (LFS/LFL) syndromes and negative for TP53 mutations were screened for germline CNVs.

Results: We found a significantly increased number of rare CNVs, which were smaller in size and presented higher gene density compared to the control group. These data were similar to the findings we reported previously on a cohort of patients with germline TP53 mutations, showing that LFS/LFL patients, regardless of their TP53 status, also share similar CNV profiles.

Conclusion: These results, in conjunction with our previous analyses, suggest that both TP53-negative and positive LFS/LFL patients present a broad spectrum of germline genetic alterations affecting multiple loci, and that the genetic basis of LFS/LFL predisposition or penetrance in many cases might reside in germline transmission of CNVs.

Keywords: Li Fraumeni syndrome, Rare CNVs, Familial cancer

\section{Introduction}

Li-Fraumeni syndrome (LFS) is an inherited condition characterized by early-onset sarcoma, brain, breast and other cancers. Families with incomplete LFS features are referred to as Li-Fraumeni-like (LFL) [1,2]. Germline mutations in the tumor suppressor gene TP53 account for over $50 \%$ of the families matching LFS criteria [3] but for only $20-40 \%$ of the LFL families [4]; lack of TP53 mutation in a significant proportion of LFS/LFL families, suggests that other types of inherited alterations must contribute to their cancer susceptibility. Although point

\footnotetext{
* Correspondence: amandagonc@yahoo.com

'Department of Genetics and Evolutionary Biology, Institute of Biosciences, University of São Paulo, Rua do Matão, 277-05422-970 São Paulo, São Paulo, Brazil

Full list of author information is available at the end of the article
}

mutations have been commonly described, DNA copy number variations ( $\mathrm{CNVs}$ ) have been reported as an alternative mechanism for cancer predisposition for at least 30\% of known Mendelian cancer genes [5,6], including TP53 [7,8], APC [9], BRCA1 [10] and the mismatch repair gene $\mathrm{MSH} 2$ [9].

We used microarray-based comparative genomic hybridization (array-CGH) to screen for CNVs in the germline DNA of 70 patients fulfilling diagnostic criteria for LFS or LFL, but with no detectable mutation involving TP53 [11]. Results were compared to a random sample of 100 Brazilian control individuals [12], to a sample of LFS/LFL TP53 mutated patients previously published by us [13], and to publically available CNV data in normal individuals (DGV). 


\section{Subjects and methods Patients}

The patients were recruited and ascertained at the Department of Oncogenetics of the A. C. Camargo Cancer Center, São Paulo, Brazil. The protocol was approved by the ethics committee of the institution and informed consent obtained from all subjects and their families. DNA was isolated from peripheral leukocytes using standard protocols. The cohort comprised 70 non-related probands fulfilling either the classical definition of LFS or at least one of the clinical criteria commonly defining LFL (Chompret, Birch or Eeles's definitions) [14-17]. These DNA samples had been previously shown to have no mutations in the coding sequences (exons 2 to 11) or splice junctions of the TP53 gene [18].

\section{Controls}

The CNV data of a group of 100 individuals randomly selected from the urban area of São Paulo, Brazil, was used as control for this study as previously described [12].

\section{Array-CGH}

Array-CGH was performed using a $180 \mathrm{~K}$ whole-genome platform (design 22060, Agilent Technologies, Santa Clara, USA), with an average spacing of $18 \mathrm{~Kb}$ between probes. Scanned images of the arrays were processed and analyzed using Feature Extraction software and Genomic Workbench software (both from Agilent Technologies), together with the statistical algorithm ADM-2, and using a sensitivity threshold of 6.7. We applied a 'loop design' in our hybridizations as previously described [19], resulting in two reverse labeling hybridizations per sample. Alterations had to encompass at least three consecutive probes with aberrant $\log _{2}$ values to be called by the software, and those not detected in both dye-swap experiments were excluded from the analysis.

\section{Analysis}

The detected copy number variations were compared to CNVs reported in the Database of Genomic Variants (DGV; http://dgv.tcag.ca/dgv/app/home; freeze December, 2011). We arbitrarily classified CNVs into "rare" and "common" by considering as "rare" those CNVs encompassing coding sequences and present in frequencies $<0.1 \%$ in DGV, that does not exclude that some rare CNVs might contain smaller segments which can vary in copy number in the population. Mann-Whitney and Fisher-exact tests were used to compare patients and controls for frequency, gene density and size distribution of CNVs.

Gene annotation was performed using the University of California Santa Cruz Genome Browser (UCSC) and the Catalog of Somatic Mutations (COSMIC; http:// cancer.sanger.ac.uk/cancergenome/projects/cosmic/).

\section{Results}

The clinical classification of the patients, description of their cancer types and age at onset are given in Additional file 1: Table S1. A total of $567 \mathrm{CNVs}$ were identified in the 70 patients investigated (308 losses and 259 gains). Table 1 presents the CNV features detected in the LFS/LFL patients without TP53 mutations, the previously published CNV data from LFS/LFL patients with mutation [13] and controls. Full CNV data are presented in Additional file 2: Table S2.

No significant differences were found between the TP53-negative patients compared to controls regarding the number of common CNVs per genome or ratio of losses to gains. However, there was a significantly higher number of rare CNVs per genome in this patient group $(\mathrm{p}=0.014$; Mann-Whitney test) (Figure 1A). With respect to CNV size, the CNVs in the TP53-negative patients were significantly smaller than controls both for common (Figure 1B) and rare (Figure 1C) CNVs ( $<<0.001$; MannWhitney test).

Furthermore, the mean number of genes encompassed by rare alterations per $\mathrm{Mb}$ (gene density) was much higher in patients with 31 genes per $\mathrm{Mb}$ as opposed to 9 in controls $(\mathrm{p}<0.0001$; Mann Whitney test) (Figure 1D).

In addition, while no recurrence was found among the rare CNVs in control individuals, 4 rare $\mathrm{CNV}$ regions were either recurrent or partially overlapping in 2 independent patients for each region (Table 2).

\section{Discussion}

Despite extensive search for other genes underlying LFS/ LFL, no genes other than TP53 have been consistently associated with this complex syndrome. However, patient series in the US and Europe have shown that only $\sim 30 \%$ of those subjects tested for TP53 mutation because of familial predisposition or early-onset of cancer turned out to be positive. This strongly suggests that genetic factors other than TP53 mutations must be contributing to familial predisposition cancer in many LFS/ LFL subjects.

We previously described an increased number of CNVs in Brazilian Li-Fraumeni patients carrying germline mutations in the TP53 gene, and also reported an increased number of rare CNVs per genome in patients carrying mutations that affected the DNA binding domain (DBD) of the TP53 gene compared to both controls and p.R337H mutants [13]. The Brazilian founder mutation p.R337H has a markedly less severe impact on tumor predisposition $[20,21]$ and has a CNV profile much closer to controls than the TP53 DBD mutations [13]. A similar, but milder increase in number of rare CNVs was observed among non-mutated patients. In a previous article [13], we speculated that an increase of rare $\mathrm{CNVs}$ could result from inefficient selection against 
Table 1 Features of the detected CNVs in TP53 mutated and non-mutated patients compared to controls: size, number of genes, and gene density

\begin{tabular}{|c|c|c|c|c|c|c|c|c|c|}
\hline & $\begin{array}{l}\text { TP53 type of } \\
\text { mutation }\end{array}$ & $\begin{array}{l}\text { Number of } \\
\text { individuals }\end{array}$ & $\begin{array}{l}\text { Number of CNVs } \\
\text { (rare/common) }\end{array}$ & $\begin{array}{l}\text { Mean number of } \\
\text { common CNVs }\end{array}$ & $\begin{array}{l}\text { Mean size of } \\
\text { common CNVs (Kb) }\end{array}$ & $\begin{array}{l}\text { Gene density of } \\
\text { common CNVs } \\
\text { (gene number/Mb) }\end{array}$ & $\begin{array}{l}\text { Mean number } \\
\text { of rare CNVs }\end{array}$ & $\begin{array}{l}\text { Mean size of } \\
\text { rare CNVs (Kb) }\end{array}$ & $\begin{array}{l}\text { Gene density } \\
\text { of rare CNVs } \\
\text { (gene number/Mb) }\end{array}$ \\
\hline \multirow[t]{3}{*}{ TP53- mutated* } & DNA binding domain & 9 & $10 / 56$ & $7.33 \pm 2.5$ & $165.0 \pm 233.3$ & 14.0 & $\begin{array}{l}1.11 \pm 1.2 \\
(p=0.0086)\end{array}$ & $168.7 \pm 202.8$ & $15.4(p=0.0159)$ \\
\hline & $\mathrm{R} 337 \mathrm{H}$ & 12 & $3 / 89$ & $7.67 \pm 2.1$ & $186.6 \pm 343.0(p=0.0032)$ & 10.4 & $0.25 \pm 0.6$ & $204 \pm 161.6$ & 8.1 \\
\hline & All & 21 & $13 / 145$ & $7.6 \pm 2.3$ & $178.2 \pm 304.6(p=0.0022)$ & 12.8 & $0.65 \pm 1.0$ & $176.8 \pm 188.3$ & $13.4(p=0.0367)$ \\
\hline TP53-wild type & & 70 & $40 / 527$ & $7.5 \pm 2.6$ & $208.7 \pm 459.9(p=0.0008)$ & 9.0 & $\begin{array}{l}0.57 \pm 0.9 \\
(p=0.0145)\end{array}$ & $\begin{array}{l}94.5 \pm 101.8 \\
(p=0.0001)\end{array}$ & $31.4(p=0.0001)$ \\
\hline Controls & & 100 & $23 / 679$ & $6.7 \pm 3.0$ & $236.7 \pm 454.0$ & 8.8 & $0.23 \pm 0.4$ & $232.2 \pm 152.7$ & 8.6 \\
\hline
\end{tabular}

*Previously published results [13]. 

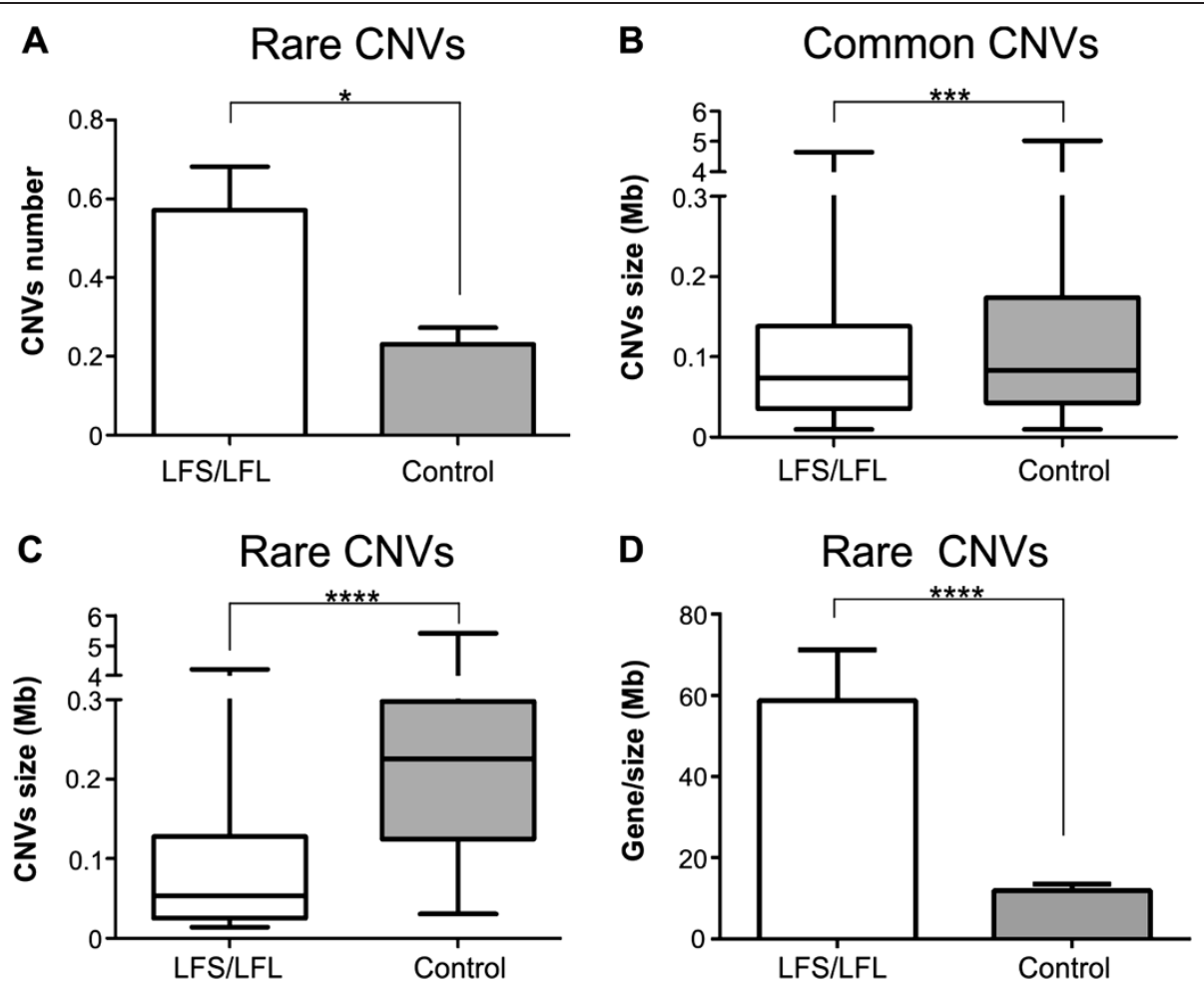

Figure 1 Comparison between the CNVs in Li-Fraumeni patients and controls. (A) Frequency of rare CNVs; (B) Size of common CNVs; (C) Size of rare CNVs; (D) Gene density in LFS patients and controls. Mann-Whitney test; ${ }^{*} p=0.014$; ${ }^{* * *} p<0.001$, ${ }^{* * *} p<0.0001$.

pathogenic CNVs, due to failure or reduction in apoptosis driven by TP53 germline mutations. Similarly, in this new study of TP53-negative patients, increases in the number of rare CNVs could result from mutations in genes other than TP53, possibly in the TP53 pathway, as previously suggested [22-24]. Such an example was recently reported by us [25] in a patient of the present cohort and involved the deletion of the full $B A X$ gene, which is directly activated by the TP53 protein. The very high gene content of rare CNVs in TP53-negative patients (an almost four-fold increase compared to controls) suggests that these CNVs are under strong selective pressure, and that their gene content likely contribute to oncogenesis. Interestingly, TP53-mutated patients also exhibit increased gene density, although this phenomenon is much less striking than in the nonmutated patients (Table 1). These results show that LFS/ LFL patient's, with the exception of those carrying the p.R337H mutation, share similar $\mathrm{CNV}$ profiles regardless of their mutation status.

The recurrent regions detected in the rare CNVs in our study encompass several genes with potential functional relevance to carcinogenesis, including $M A D 1 L 1$, DOT1L1, MAGEA8 and MAGEA9. MAD1L1 encodes a protein that plays an important role in maintaining spindle checkpoint functions and alterations in this gene

Table 2 Recurrent CNV regions in patients without TP53 mutation

\begin{tabular}{|c|c|c|c|c|c|c|c|c|c|c|}
\hline$\overline{C h r}$ & $\begin{array}{l}\text { Start } \\
\text { position }\end{array}$ & $\begin{array}{l}\text { End } \\
\text { position }\end{array}$ & Type & Size & Genes associated & Patient & Tumor & $\begin{array}{l}\text { Age of } \\
\text { onset }\end{array}$ & Tumor & $\begin{array}{l}\text { Age of } \\
\text { onset }\end{array}$ \\
\hline chrX & 148653235 & 148789920 & Gain & 136685 & HSFX1, HSFX1, MAGEA9, MAGEA8 & Y0123T000 & Breast & 37 & Breast & 37 \\
\hline chrX & 148638057 & 148835731 & Gain & 197674 & HSFX1, HSFX1, MAGEA9, MAGEA8 & Y006T00 & STS & 15 & Breast & 32 \\
\hline chr19 & 2173067 & 2187671 & Gain & 14604 & DOT1L, PLEKHJ1, hsa-mir-1227 & Y101T000 & Breast & 48 & Thyroid & 52 \\
\hline chr19 & 2173067 & 2187671 & Loss & 14604 & DOT1L, PLEKHJ1, hsa-mir-1227 & Y0114T000 & Osteosarcoma & 30 & & \\
\hline chr5 & 140207385 & 140243110 & Gain & 35725 & PCDHA11, PCDHA12, PCDHA13 & Y0110T000 & Breast & 36 & & \\
\hline chr5 & 140207385 & 140243110 & Loss & 35725 & PCDHA11, PCDHA12, PCDHA13 & Y0112T000 & Breast & 34 & & \\
\hline chr7 & 2182941 & 2234914 & Gain & 51973 & MAD1L1 & Y0143T000 & Breast & 42 & & \\
\hline chr7 & 2182941 & 2244756 & Loss & 61815 & MAD1L1, FTSJ2 & Y0123T000 & Bilateral breast & 37,37 & & \\
\hline
\end{tabular}

STS - soft tissue sarcoma. 
have been associated with colon, lung, prostate and breast cancers $[26,27]$. The histone methyltransferase DOT1L1 is involved in leukemia [28]. The MAGE gene family encodes proteins only expressed on normal germ cells of the testis but are ectopically expressed in melanomas and in a variety of other common cancer types [29]. Although the frequency of each recurrent region is individually low, as a group, rare $\mathrm{CNVs}$ may represent a significant contributor to the etiology of LFS/LFL.

Although the potential role of CNVs as genetic risk factors to cancer predisposition has not yet been fully defined, there is now compelling evidence that cancer-related genes may be encompassed or overlapped by common CNVs. Shlien et al. [30] found a significant enrichment of CNVs in LFS probands; among the genes encompassed by common CNVs, they reported recurrence of a duplication of MLLT4, a target of the RAS pathway. In agreement with this, we also detected common MLLT4 duplications in three of the TP53-negative patients but none in the controls. We have also recently reported a $691 \mathrm{~kb}$ recurrent deletion at $7 \mathrm{q} 34$ harboring only the PIP and TAS2R39 genes [31] in five patients with high cancer predisposition from different cohorts, including two TP53-negative patients from the present study and one TP53-positive LFS patient. Common cancer CNVs, such as the ones harboring MLLT4 and PIP, most likely confer a minor increase in disease risk that collectively or in association with highly penetrant mutations may cause a substantially elevated risk.

\section{Conclusion}

These findings support the hypothesis that in LFS/LFL families not carrying TP53 mutations, cancer predisposition may be caused by a broad spectrum of genetic alterations affecting multiple loci. How CNVs and other genetic modifiers interact and modulate TP53 tumor suppressor activities remain to be determined. Elucidating these mechanisms may hold the key to define evidencebased strategies for counseling using combined risks from TP53 and other variants, including CNVs.

\section{Availability of supporting data}

The data set supporting the results of this article is included within the article and its additional files.

\section{Additional files}

Additional file 1: Table S1. Clinical classification, gender, cancer type and age at onset of the patients.

Additional file 2: Table S2. Full CNV data on the 70 probands, rare CNVs in bold-chromosome coordinates given according to $\mathrm{Hg} 18$.

\section{Abbreviations}

LFS: Li-Fraumeni syndrome; LFL: Li-Fraumeni like syndrome; CNV: Copy number variation.

\section{Competing interests}

The authors declare that they have no competing interests.

\section{Authors' contributions}

AGS carried out the molecular genetic studies. AGS and PLP wrote the manuscript. ACVK and CR participated in the design and coordination of the study and helped writing the manuscript. MIWA recruited and selected the patients. All authors read and approved the final manuscript.

\section{Acknowledgments}

We thank all patients for their participation to this study. This work was supported by Sao Paulo Research Foundation-FAPESP (2009/00898-1 and 2008/57887-9) and The Brazilian National Council for Scientific and Technological Development-CNPq (573589/08-9).

\section{Author details}

'Department of Genetics and Evolutionary Biology, Institute of Biosciences, University of São Paulo, Rua do Matão, 277-05422-970 São Paulo, São Paulo, Brazil. ${ }^{2}$ International Center for Research and Training, A. C. Camargo Cancer Center, Rua Taguá, 440-01508-010 São Paulo, Brazil. ${ }^{3}$ International Prevention Research Institute, 15 Chemin du Saquin, 69130 Ecully, France. ${ }^{4}$ Department of Oncogenetics, International Center for Research and Training, A. C. Camargo Cancer Center, Rua Taguá, 440-01508-010 São Paulo, Brazil.

Received: 2 January 2014 Accepted: 16 April 2014

Published: 28 April 2014

\section{References}

1. Li FP, Fraumeni JF, Mulvihill JJ, Blattner WA, Dreyfus MG, Tucker MA, Miller RW: A cancer family syndrome in twenty-four kindreds. Cancer Res 1988, 48(18):5358-5362.

2. Birch JM, Alston RD, McNally RJ, Evans DG, Kelsey AM, Harris M, Eden OB, Varley JM: Relative frequency and morphology of cancers in carriers of germline TP53 mutations. Oncogene 2001, 20(34):4621-4628.

3. Malkin D, Li FP, Strong LC, Fraumeni JF, Nelson CE, Kim DH, Kassel J, Gryka MA, Bischoff FZ, Tainsky MA: Germ line p53 mutations in a familial syndrome of breast cancer, sarcomas, and other neoplasms. Science 1990, 250(4985):1233-1238.

4. Nagy R, Sweet K, Eng C: Highly penetrant hereditary cancer syndromes. Oncogene 2004, 23(38):6445-6470.

5. Kuiper RP, Ligtenberg MJ, Hoogerbrugge N, Geurts van Kessel A: Germline copy number variation and cancer risk. Curr Opin Genet Dev 2010, 20(3):282-289.

6. Krepischi AC, Pearson PL, Rosenberg C: Germline copy number variations and cancer predisposition. Future Oncol 2012, 8(4):441-450.

7. Bougeard G, Brugières L, Chompret A, Gesta P, Charbonnier F, Valent A, Martin C, Raux G, Feunteun J, Bressac-de Paillerets B, Frébourg T: Screening for TP53 rearrangements in families with the Li-Fraumeni syndrome reveals a complete deletion of the TP53 gene. Oncogene 2003, 22(6):840-846.

8. Bougeard G, Sesboüé R, Baert-Desurmont S, Vasseur S, Martin C, Tinat J, Brugières L, Chompret A, de Paillerets BB, Stoppa-Lyonnet D, Bonaïti-Pellié C, Frébourg T, French LFS Working Group: Molecular basis of the Li-Fraumeni syndrome: an update from the French LFS families. J Med Genet 2008, 45(8):535-538.

9. Bunyan DJ, Eccles DM, Sillibourne J, Wilkins E, Thomas NS, Shea-Simonds J, Duncan PJ, Curtis CE, Robinson DO, Harvey JF, Cross NC: Dosage analysis of cancer predisposition genes by multiplex ligation-dependent probe amplification. Br J Cancer 2004, 91(6):1155-1159.

10. Goncalves A, Ewald IP, Sapienza M, Pinheiro M, Peixoto A, Nobrega AF, Carraro DM, Teixeira MR, Ashton-Prolla P, Achatz MI, Rosenberg C, Krepischi AC: Li-Fraumeni-like syndrome associated with a large BRCA1 intragenic deletion. BMC Cancer 2012, 12(1):237.

11. Marcel V, Palmero El, Falagan-Lotsch P, Martel-Planche G, Ashton-Prolla P, Olivier M, Brentani RR, Hainaut P, Achatz MI: TP53 PIN3 and MDM2 SNP309 polymorphisms as genetic modifiers in the Li-Fraumeni syndrome: impact on age at first diagnosis. J Med Genet 2009, 46(11):766-772.

12. Krepischi AC, Achatz MI, Santos EM, Costa SS, Lisboa BC, Brentani H, Santos TM, Goncalves A, Nobrega AF, Pearson PL, Vianna-Morgante AM, Carraro DM, Brentani RR, Rosenberg C: Germline DNA copy number variation in familial and early-onset breast cancer. Breast Cancer Res 2012, 14(1):R24. 
13. Silva AG, Achatz IMW, Krepischi AC, Pearson PL, Rosenberg C: Number of rare germline CNVs and TP53 mutation types. Orphanet J Rare Dis 2012, 7:101.

14. Birch JM, Hartley AL, Tricker KJ, Prosser J, Condie A, Kelsey AM, Harris M, Jones PH, Binchy A, Crowther D, Lane DP, Craft AW, Eden OB, Evans DGR, Thompson E, Mann JR, Martin J, Mitchell ELD, Santibáñez-Koref MF: Prevalence and diversity of constitutional mutations in the p53 gene among 21 Li-Fraumeni families. Cancer Res 1994, 54:1298-1304.

15. Eeles RA: Germline mutations in the TP53 gene. Cancer Surv 1995, 25:101-124.

16. Chompret $A$, Brugières $L$, Ronsin $M$, Gardes $M$, Dessarps-Freichey F, Abel $A$, Hua D, Ligot L, Dondon MG, Bressac-de Paillerets B, Frébourg T, Lemerle J, Bonaiti-Pellié C, Feunteun J: P53 germline mutations in childhood cancers and cancer risk for carrier individuals. Br J Cancer 2000, 82(12):1932-1937.

17. Chompret A, Abel A, Stoppa-Lyonnet D, Brugiéres L, Pagés S, Feunteun J, Bonaïti-Pellié C: Sensitivity and predictive value of criteria for p53 germline mutation screening. J Med Genet 2001, 38(1):43-47.

18. Li FP, Fraumeni JF: Soft-tissue sarcomas, breast cancer, and other neoplasms. A familial syndrome? Ann Intern Med 1969, 71(4):747-752.

19. Allemeersch J, Van Vooren S, Hannes F, De Moor B, Vermeesch JR, Moreau $Y$ : An experimental loop design for the detection of constitutional chromosomal aberrations by array CGH. BMC Bioinformatics 2009, 10:380

20. DiGiammarino EL, Lee AS, Cadwell C, Zhang W, Bothner B, Ribeiro RC, Zambetti G, Kriwacki RW: A novel mechanism of tumorigenesis involving pH-dependent destabilization of a mutant p53 tetramer. Nat Struct Biol 2002, 9(1):12-16.

21. Zambetti GP: The p53 mutation "gradient effect" and its clinical implications. J Cell Physiol 2007, 213(2):370-373.

22. Bell DW, Varley JM, Szydlo TE, Kang DH, Wahrer DC, Shannon KE, Lubratovich M, Verselis SJ, Isselbacher KJ, Fraumeni JF, Birch JM, Li FP. Garber JE, Haber DA: Heterozygous germ line hCHK2 mutations in Li-Fraumeni syndrome. Science 1999, 286(5449):2528-2531.

23. Vahteristo P, Tamminen A, Karvinen P, Eerola H, Eklund C, Aaltonen LA, Blomqvist C, Aittomäki K, Nevanlinna H: p53, CHK2, and CHK1 genes in Finnish families with Li-Fraumeni syndrome: further evidence of $\mathrm{CHK} 2$ in inherited cancer predisposition. Cancer Res 2001, 61(15):5718-5722.

24. Barlow JW, Mous M, Wiley JC, Varley JM, Lozano G, Strong LC, Malkin D: Germ line BAX alterations are infrequent in Li-Fraumeni syndrome. Cancer Epidemiol Biomarkers Prev 2004, 13(8):1403-1406.

25. Silva AG, Lisboa BC, Achatz MI, Carraro DM, da Cunha IW, Pearson PL, Krepischi $A C$, Rosenberg C: Germline BAX deletion in a patient with melanoma and gastrointestinal stromal tumor. Am J Gastroenterol 2013, 108(8):1372-1375.

26. Tsukasaki K, Miller CW, Greenspun E, Eshaghian S, Kawabata H, Fujimoto T, Tomonaga M, Sawyers C, Said JW, Koeffler HP: Mutations in the mitotic check point gene, MAD1L1, in human cancers. Oncogene 2001, 20(25):3301-3305.

27. Guo Y, Zhang X, Yang M, Miao X, Shi Y, Yao J, Tan W, Sun T, Zhao D, Yu D, Liu J, Lin D: Functional evaluation of missense variations in the human MAD1L1 and MAD2L1 genes and their impact on susceptibility to lung cancer. J Med Genet 2010, 47(9):616-622.

28. Krivtsov AV, Armstrong SA: MLL translocations, histone modifications and leukaemia stem-cell development. Nat Rev Cancer 2007, 7(11):823-833.

29. Sang M, Wang L, Ding C, Zhou X, Wang B, Lian Y, Shan B: Melanomaassociated antigen genes - an update. Cancer Lett 2011, 302(2):85-90.

30. Shlien A, Tabori U, Marshall CR, Pienkowska M, Feuk L, Novokmet A, Nanda S, Druker H, Scherer SW, Malkin D: Excessive genomic DNA copy number variation in the Li-Fraumeni cancer predisposition syndrome. Proc Natl Acad Sci U S A 2008, 105(32):11264-11269.

31. Silva AG, Krepischi AC, Torrezan GT, Capelli LP, Carraro DM, D'Angelo CS, Koiffmann CP, Zatz M, Naslavsky MS, Masotti C, Otto PA, Achatz MIW, Mills RE, Lee C, Pearson PL, Rosenberg C: Does germ-line deletion of the PIP gene constitute a widespread risk for cancer? Eur J Hum Genet 2013, 22:307-309.

doi:10.1186/1750-1172-9-63

Cite this article as: Silva et al: The profile and contribution of rare germline copy number variants to cancer risk in Li-Fraumeni patients negative for TP53 mutations. Orphanet Journal of Rare Diseases 2014 9:63.

\section{Submit your next manuscript to BioMed Central and take full advantage of:}

- Convenient online submission

- Thorough peer review

- No space constraints or color figure charges

- Immediate publication on acceptance

- Inclusion in PubMed, CAS, Scopus and Google Scholar

- Research which is freely available for redistribution 